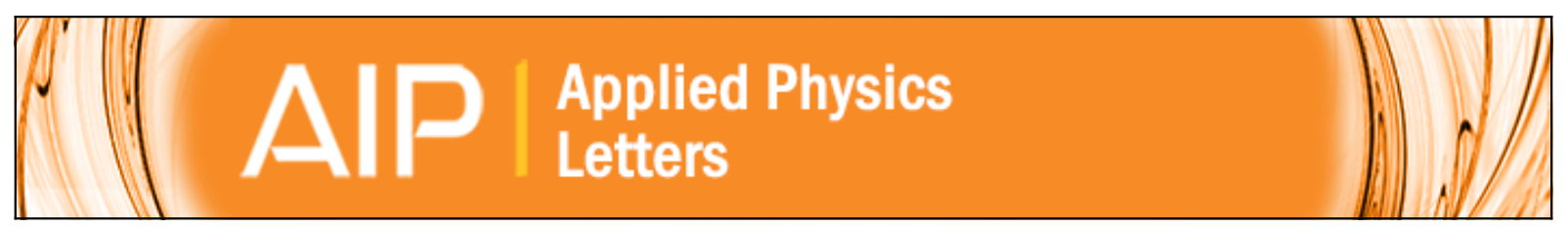

\title{
Graded band gap GalnNAs solar cells
}

F. Langer, S. Perl, S. Höfling, and M. Kamp

Citation: Applied Physics Letters 106, 233902 (2015); doi: 10.1063/1.4922279

View online: http://dx.doi.org/10.1063/1.4922279

View Table of Contents: http://scitation.aip.org/content/aip/journal/apl/106/23?ver=pdfcov

Published by the AIP Publishing

\section{Articles you may be interested in}

p- to n-type conductivity transition in $1.0 \mathrm{eV}$ GalnNAs solar cells controlled by the V/III ratio

Appl. Phys. Lett. 106, 063905 (2015); 10.1063/1.4909507

Comparison of GalnNAs and GalnNAsSb solar cells grown by plasma-assisted molecular beam epitaxy AIP Conf. Proc. 1477, 49 (2012); 10.1063/1.4753831

High quantum efficiency InGaN/GaN solar cells with $2.95 \mathrm{eV}$ band gap

Appl. Phys. Lett. 93, 143502 (2008); 10.1063/1.2988894

Low-acceptor-concentration GalnNAs grown by molecular-beam epitaxy for high-current $\mathrm{p}$ - $\mathrm{i}$ - $\mathrm{n}$ solar cell applications

J. Appl. Phys. 98, 094501 (2005); 10.1063/1.2113414

Photoreflectance evidence of multiple band gaps in dilute GalnNAs layers lattice-matched to GaAs

J. Appl. Phys. 96, 2576 (2004); 10.1063/1.1776312

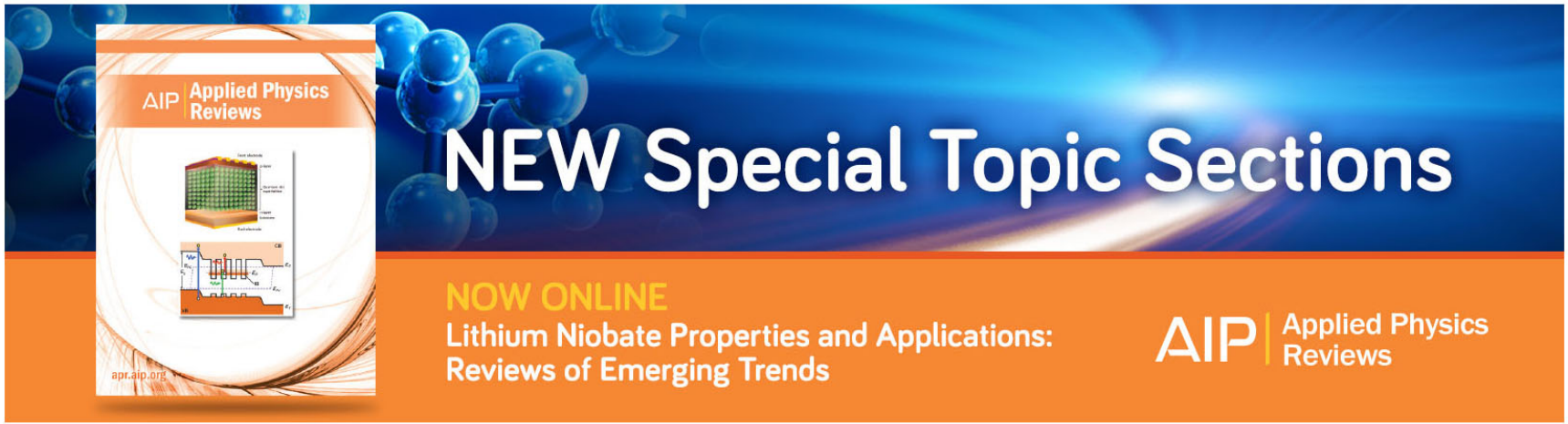




\title{
Graded band gap GalnNAs solar cells
}

\author{
F. Langer, ${ }^{1}$ S. Perl, ${ }^{1}$ S. Höfling, ${ }^{1,2}$ and M. Kamp ${ }^{1}$ \\ ${ }^{1}$ Technische Physik, Physikalisches Institut and Wilhelm Conrad Röntgen Research Center for Complex, \\ Material Systems, University of Würzburg, Am Hubland, Würzburg D97074, Germany \\ ${ }^{2}$ SUPA, School of Physics and Astronomy, University of St Andrews, St Andrews KY16 9SS, United Kingdom
}

(Received 27 March 2015; accepted 27 May 2015; published online 8 June 2015)

\begin{abstract}
Dilute nitride $\mathrm{GaInN}(\mathrm{Sb}) \mathrm{As}$ with a band gap $\left(\mathrm{E}_{\mathrm{g}}\right)$ of $1.0 \mathrm{eV}$ is a promising material for the integration in next generation multijunction solar cells. We have investigated the effect of a compositionally graded GaInNAs absorber layer on the spectral response of a GaInNAs sub cell. We produced band gap gradings $\left(\Delta \mathrm{E}_{\mathrm{g}}\right)$ of up to $39 \mathrm{meV}$ across a $1 \mu \mathrm{m}$ thick GaInNAs layer. Thereby, the external quantum efficiency-compared to reference cells-was increased due to the improved extraction of photo-generated carriers from $34.0 \%$ to $36.7 \%$ for the wavelength range from $900 \mathrm{~nm}$ to $1150 \mathrm{~nm}$. However, this device figure improvement is accompanied by a small decrease in the open circuit voltage of about $20 \mathrm{mV}$ and the shift of the absorption edge to shorter wavelengths. (c) 2015 AIP Publishing LLC. [http://dx.doi.org/10.1063/1.4922279]
\end{abstract}

Multi-junction solar cells comprised of semiconductors with different $\mathrm{E}_{\mathrm{g}}$ make the most efficient use of the broad solar spectrum. There are different methods for the fabrication of such devices. For instance, wafer bonding of semiconductors with optimized $\mathrm{E}_{\mathrm{g}}$ recently improved the world record up to $46.0 \%$ at a concentration of 508 suns. ${ }^{1}$ Nevertheless, the established industry standard for mass production is still the monolithic growth of the material combination GaInP/ $\mathrm{Ga}(\mathrm{In}) \mathrm{As} / \mathrm{Ge}$. These structures could already be improved by the integration of an additional $1.0 \mathrm{eV} \mathrm{GaInN(Sb)As} \mathrm{middle}$ junction that can be grown lattice matched to Ge/GaAs in one epitaxial process. ${ }^{2}$ However, the incorporation of $\mathrm{N}$ atoms usually increases the formation of deep level defects with detrimental effects on the electrical properties of the material, ${ }^{3-6}$ resulting in low minority carrier diffusion lengths limiting the current generation in $\mathrm{GaInN}(\mathrm{Sb}) \mathrm{As}$ junctions. ${ }^{7,8}$ A current method is the use of p-i-n structures with wide depletion zones to deal with these issues. The challenge of this approach is to achieve residual carrier densities in the $10^{15} \mathrm{~cm}^{-3}$ range, whereas epitaxially grown $\mathrm{GaInN}(\mathrm{Sb}) \mathrm{As}$ material usually shows an electrically active carrier concentration in the mid $10^{16} \mathrm{~cm}^{-3}$. Especially, electrically active defects like Ga-vacancies are identified as a possible source for high p-type doping levels. ${ }^{9-11}$ Another way to increase the current collection can be the introduction of an additional internal potential gradient in the undepleted material or over the entire GaInN(Sb)As layer. This would impose a drift velocity on the photo-generated charge carriers helping to extract them effectively. There are different possibilities to create such a gradient. One approach is the introduction of graded doping profiles in the emitter or the base of the $\mathrm{GaInN}(\mathrm{Sb}) \mathrm{As}$ layer. In this paper, we present a different solution that is based on the introduction of compositionally graded GaInNAs material producing a graded band gap. This technique was already shown to be useful in the case of $\mathrm{Al}_{\mathrm{x}} \mathrm{Ga}_{(1-\mathrm{x})} \mathrm{As}$ and CIGS solar cells. ${ }^{12,13}$

The structures used for this work were grown in a 3 in. EIKO molecular beam epitaxy machine with standard solid sources, aside from $\mathrm{N}$ which is provided as atomic species by a radio frequency plasma source. We used Zn-doped GaAs (100) wafers with $6^{\circ}$ offcut to the (111)B planes as substrates. The growth temperature of the GaInNAs layers was $380^{\circ} \mathrm{C}$ and all samples were subjected to a post-growth anneal at $700{ }^{\circ} \mathrm{C}$ for $20 \mathrm{~min} . \mathrm{Ga}_{(1-\mathrm{x})} \operatorname{In}_{\mathrm{x}} \mathrm{N}_{\mathrm{y}} \mathrm{As}_{(1-\mathrm{y})}$ can be grown within a broad range of $\mathrm{E}_{\mathrm{g}}$ while staying lattice matched to GaAs as long as $\mathrm{x} \approx 3 \mathrm{y}$. To change the $\mathrm{E}_{\mathrm{g}}$ of the GaInNAs alloy, its composition has to be adjusted accordingly. This procedure is straightforward for the growth of GaInNAs material with a fixed composition. However, for the epitaxy of a compositionally graded GaInNAs layer, the fluxes of the effusion cells have to be changed during the growth process. This has to be done in a very precise way to keep the material lattice matched to GaAs over the full range of compositions. In this context, we have grown various $1 \mu \mathrm{m}$ thick graded and ungraded $\mathrm{Ga}_{(1-\mathrm{x})} \mathrm{In}_{\mathrm{x}} \mathrm{N}_{\mathrm{y}} \mathrm{As}_{(1-\mathrm{y})}$ layers on $200 \mathrm{~nm}$ thick GaAs buffer layers and capped them with $100 \mathrm{~nm}$ thick GaAs. We did not apply any intentional doping. The As-beam equivalent pressure during the growth was $9.6 \times 10^{-6}$ Torr. The nominal compositions of these samples are shown in Table I. Samples A, B, and C have been grown with constant compositions, and their growth condition was used as starting $(\mathrm{A})$ and end condition $(\mathrm{B}, \mathrm{C})$ for the samples with the graded compositions $\mathrm{A} \rightarrow \mathrm{C}$ and $\mathrm{A} \rightarrow \mathrm{B}$. During the growth of the graded GaInNAs layers, the flux ratios of the effusion cells were changed linearly between this start

TABLE I. Summary of grown $\mathrm{Ga}_{(1-\mathrm{x})} \operatorname{In}_{\mathrm{x}} \mathrm{N}_{\mathrm{y}} \mathrm{As}_{(1-\mathrm{y})}$ films.

\begin{tabular}{lcccc}
\hline \hline Sample & $x / \Delta x^{\mathrm{a}}$ & $y / \Delta y^{\mathrm{a}}$ & $E_{g}{ }^{b} / \Delta E_{g}{ }^{c}(\mathrm{eV})$ & $\begin{array}{c}\text { Lattice } \\
\text { mismatch }(\%)\end{array}$ \\
\hline $\mathrm{A}$ & $0.069 / 0$ & $0.0230 / 0$ & $1.050 / 0$ & 0.012 \\
$\mathrm{~B}$ & $0.075 / 0$ & $0.0250 / 0$ & $1.038 / 0$ & 0.005 \\
$\mathrm{C}$ & $0.083 / 0$ & $0.0277 / 0$ & $1.011 / 0$ & 0.008 \\
$\mathrm{~A} \rightarrow \mathrm{C}$ & $-/ 0.014$ & $-/ 0.0047$ & $-/ 0.039$ & 0.027 \\
$\mathrm{~A} \rightarrow \mathrm{B}$ & $-/ 0.006$ & $-/ 0.0020$ & $-/ 0.012$ & 0.005 \\
\hline \hline
\end{tabular}

\footnotetext{
${ }^{\mathrm{a}} \Delta \mathrm{x} / \Delta \mathrm{y}$ are the absolute change in the $\mathrm{In} / \mathrm{N}$ composition.

${ }^{\mathrm{b}} \mathrm{E}_{\mathrm{g}}$ is the band gap.

${ }^{\mathrm{c}} \Delta \mathrm{E}_{\mathrm{g}}$ is the absolute change of $\mathrm{E}_{\mathrm{g}}$ in the compositionally graded layers.
} 
and end conditions. $\Delta \mathrm{E}_{\mathrm{g}}$ represents the absolute change in $\mathrm{E}_{\mathrm{g}}$ between the samples $\mathrm{A}$ and $\mathrm{C}$ or between samples $\mathrm{A}$ and $\mathrm{B}$, respectively. To ensure that the In:N ratio stays close to 3 all the time only the Ga flux was changed. The following example clarifies this procedure qualitatively: Lowering the $\mathrm{Ga}$ flux during growth of GaInNAs, while leaving the In-, As-, and $\mathrm{N}$ flux unchanged increases the $\mathrm{In} / \mathrm{Ga}$ ratio due to the changed group-III flux ratio as well as it does increase the N/ As ratio due to the lower overall growth rate and the near unity sticking coefficient of N. These two oppositional factors cancel each other to some extent regarding their effect on the lattice constant of the resulting GaInNAs material because the In:N ratio is conserved within limits. On the other hand, the absolute In and $\mathrm{N}$ content of the material is changed and therefore also $\mathrm{E}_{\mathrm{g}}$. The Ga effusion cell was heated to a temperature equivalent to grow GaAs with a growth rate of $1100 \mathrm{~nm} / \mathrm{h}$ for the sample A, $1000 \mathrm{~nm} / \mathrm{h}$ for sample B, and $900 \mathrm{~nm} / \mathrm{h}$ for sample C. The As/III ratio was 25 for the sample A, 27 for sample B, and 30 for sample A. The Ga growth rate was obtained after measuring GaAs layer thicknesses of calibration samples with a scanning electron microscope. The $\mathrm{In} / \mathrm{Ga}$ ratio was calibrated by evaluating the lattice constant deviation of GaInAs quantum wells to GaAs detected by High Resolution X-Ray Diffraction (HRXRD) in order to get the In content of the wells. The graded $\mathrm{E}_{\mathrm{g}}$ in the GaInNAs layers of the sample $\mathrm{A} \rightarrow \mathrm{C} / \mathrm{B}$ cannot be measured directly. However, Figs. 1(a) and 1(b) show depth profiling of the samples $\mathrm{A}($ red), $\mathrm{C}$ (black), and $\mathrm{A} \rightarrow \mathrm{C}$ (blue) by Secondary Ion Mass Spectrometry (SIMS) detecting the N (identified by the molecule $\mathrm{NGa}$ ) and In content normalized to the As-signal in the GaInNAs layers. A linear fit of the raw data shows the decreasing $\mathrm{N}$ and In content in the sample $\mathrm{A} \rightarrow \mathrm{C}$ with increasing distance to the surface. The $\mathrm{N}$ and In signal intensity of the sample $\mathrm{A} \rightarrow \mathrm{C}$ is at the GaAs(cap)/GaInNAs interface in good approximation equal to the $\mathrm{N}$ and In signal intensity of the sample $\mathrm{A}$ and at the GaInNAs/GaAs(substrate) interface equal to the sample C. The $\mathrm{N}$ and In content of the sample $\mathrm{A} \rightarrow \mathrm{C}$ is decreasing linearly in between with a relative decrease of $15 \%$ and $16 \%$, justifying the assumption of a linearly graded $\mathrm{E}_{\mathrm{g}}$. These values do in good approximation correlate to the differences of the nominal $\mathrm{N}$ and In contents given in Table I. The $\mathrm{E}_{\mathrm{g}}$ of the ungraded material have been estimated by photoluminescence (PL) measurements at $300 \mathrm{~K}$ under excitation with a $980 \mathrm{~nm}$ laser with a power density in the order of $10^{-7} \mathrm{~W} / \mu \mathrm{m}^{2}$. For an estimation of the lattice mismatch of the GaInNAs layers, symmetric omega/2-theta rocking curves were performed by HRXRD to deliver the out of (400) plane spacing. All samples show very good lattice matching to GaAs but one has to note that for the compositionally graded layers only an average deviation of the GaInNAs layers to the GaAs substrate can be measured and the lattice strain may be higher locally.

Fig. 1(c) shows schematically the energy band lineup of the PL sample $\mathrm{A} \rightarrow \mathrm{C}$. Interestingly, mainly the conduction band $(\mathrm{cb})$ is affected by the grading because the introduced $\mathrm{N}$ states almost only interact with the $\mathrm{cb} .{ }^{14}$ The graded Incontent is also influencing the valence band (vb). However, we assume that the change of the valence band position is rather small due to the low absolute change of the In percentage across the GaInNAs layer. Consequently, mainly the photo generated electrons are affected by the potential gradient. We performed PL measurements of the samples A, C, and $\mathrm{A} \rightarrow \mathrm{C}$ to investigate the effect of the grading on the minority carriers generated in the graded layers without the influence of overlaying effects like doping or fabrication inconsistencies. All PL samples were thinned to $100 \mu \mathrm{m}$, and the substrate side was polished. The energy of the $980 \mathrm{~nm}$ laser photons is below the GaAs $\mathrm{E}_{\mathrm{g}}$ ensuring that the absorption takes place in the GaInNAs layer only. Fig. 1(d) shows the normalized PL spectra taken under excitation through the GaAs(cap) and the GaAs(substrate). Besides the intensity, we observed no differences regarding the PL peak position energy for the samples A (red rectangles) and C (black circles) (not shown). This finding can be expected because samples $\mathrm{A}$ and $\mathrm{C}$ have symmetric GaInNAs layers under both excitation directions. For the sample $\mathrm{A} \rightarrow \mathrm{C}$, this condition is different, as shown in Fig. 1(c). In the case when the excitation takes place through the GaAs(cap), about twothird of the light is absorbed in the uppermost $500 \mathrm{~nm}$ of the
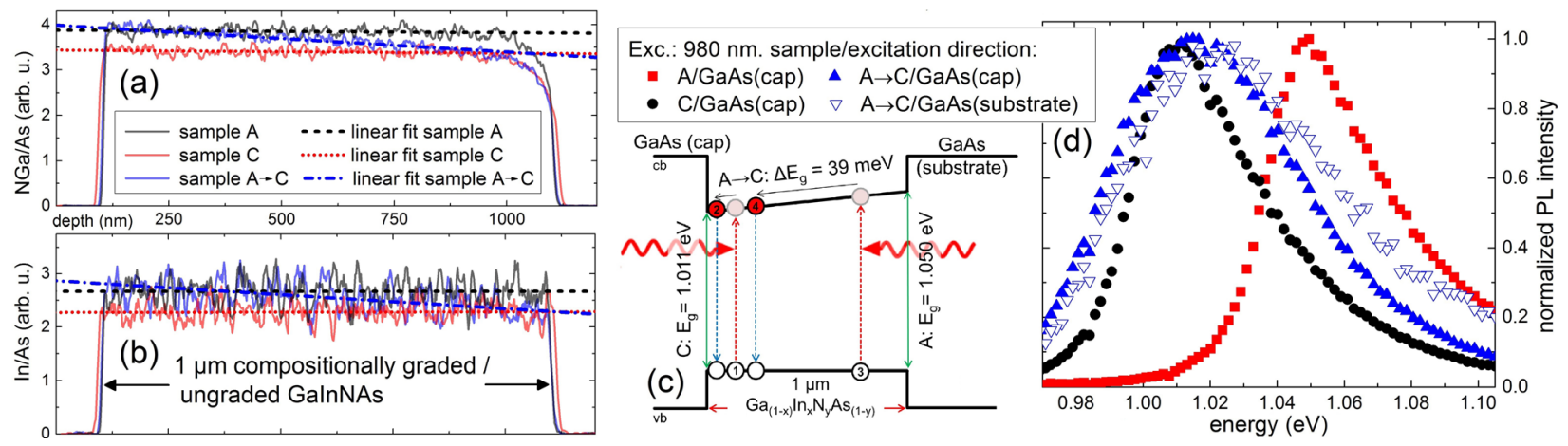

FIG. 1. (a) and (b) Depth profiling by secondary ion mass spectrometry and linear fits of the $\mathrm{N}$ and In content in the GaInNAs layers of the samples A (red, fit: points), $\mathrm{C}$ (black, fit: lines), and $\mathrm{A} \rightarrow \mathrm{C}$ (blue, fit: points and lines). The linear decrease of the $\mathrm{N}$ and In content with increasing sample depth can be seen. (c) Schematic energy band lineup of the sample A $\rightarrow$ C. Under illumination from the GaAs(cap) side, most of the light is absorbed close to the GaAs (cap) layer "1." Under illumination from the GaAs(substrate) side, the effective penetration depth until a photon is absorbed in the GaInNAs layer " 3 " is larger due to the larger band gap. In both cases, the generated electrons drift towards the decreasing band gap and recombine with a hole (process " 2 " and "4"). (d) PL spectra obtained under $980 \mathrm{~nm}$ excitation of the samples $\mathrm{A}, \mathrm{C}$, and $\mathrm{A} \rightarrow \mathrm{C}$. The tendency of the generated electrons to recombine near the position of the smallest band gap can be seen at the measurement of sample $\mathrm{A} \rightarrow \mathrm{C}$. Independent from the direction of the laser excitation is the PL peak energy located nearby the smallest band gap of the compositionally graded material (see sample C). 
GaInNAs layer (assuming an absorption coefficient $\alpha$ for $980 \mathrm{~nm}$ photons in the GaInNAs layer of $2.0 \times 10^{4} \mathrm{~cm}^{-1}$ ) illustrated by the absorption process labeled with "1." The generated electrons drift towards the decreasing $\mathrm{E}_{\mathrm{g}}$ and recombine close to the GaAs(cap)/GaInNAs interface("2"). This process can also be seen by analyzing the PL signal (blue up-pointing triangles) from sample $\mathrm{A} \rightarrow \mathrm{C}$ which has a broader full width at half maximum (FWHM) than the PL signal from sample $\mathrm{A} / \mathrm{C}$ due to its graded $\mathrm{E}_{\mathrm{g}}$. The position of the PL peak energy is $1.015 \mathrm{eV}$ and very close to the peak position of the ungraded sample $\mathrm{C}$ at $1.011 \mathrm{eV}$. One can therefore conclude that most of the generated electrons drift towards the GaAs(cap)/GaInNAs interface due to the decreasing $E_{\mathrm{g}}$. Even more significant is the condition when the laser excitation is done through the GaAs(substrate). In that case, two-thirds of the absorption takes place in the lowest $650 \mathrm{~nm}$ (assuming an $\alpha$ of $1.75 \times 10^{4} \mathrm{~cm}^{-1}$ due to the slightly larger $\mathrm{E}_{\mathrm{g}}$ ) of the GaInNAs layer, as illustrated by the absorption process labeled with "3." The generated electrons have a relatively long distance to cross in the direction of the decreasing $\mathrm{E}_{\mathrm{g}}$ towards the $\mathrm{GaAs}(\mathrm{cap}) / \mathrm{GaInNAs}$ interface until they recombine with an existing hole ("4." Representing an approximate recombination position in the GaInNAs layer estimated by the PL peak energy.). The PL signal representing the excitation through the GaAs(substrate) can be seen in Fig. 1(d) (blue down-pointing triangles). Like the PL signal attained under excitation through the GaAs(cap), the FWHM is broadened. The PL peak energy is $1.018 \mathrm{eV}$ and is clearly closer to the $\mathrm{E}_{\mathrm{g}}$ of $1.011 \mathrm{eV}$ near the GaAs(cap)/GaInNAs interface (cp. sample C) as to the $\mathrm{E}_{\mathrm{g}}$ of $1.050 \mathrm{eV}$ near the GaInNAs/GaAs(substrate) interface (cp. sample A) where most of the absorption takes place. At this point, the electron drift due to the potential gradient in the graded GaInNAs layer can be seen very clearly. However, it seems that the lifetimes of the generated electrons are not long enough to let them reach the upper end of the GaInNAs layer near the GaAs(cap)/GaInNAs interface.

The growth procedure of samples $\mathrm{A} \rightarrow \mathrm{C}$ and $\mathrm{A} \rightarrow \mathrm{B}$ has been used to integrate the compositionally graded GaInNAs in solar cell structures (solar cells $\mathrm{A} \rightarrow \mathrm{C}$ and $\mathrm{A}$ $\rightarrow$ B). For comparison, we have fabricated solar cells with the graded GaInNAs layers together with correspondent ungraded reference solar cells (solar cells $\mathrm{C}$ and $\mathrm{B}$ ), which are grown analog sample $\mathrm{C}$ for comparison with cell $\mathrm{A} \rightarrow \mathrm{C}$ and analog sample B for comparison with cell $\mathrm{A} \rightarrow \mathrm{B}$, respectively. Fig. 2(a) shows the simulation of the $\mathrm{cb}$ (red line and black points) and valance band lineups (blue broken line) of the cells $\mathrm{A} \rightarrow \mathrm{C}$ and $\mathrm{C}$ for their estimated compositions. The cells consist of a p-i-n diode with $50 \mathrm{~nm}$ $\mathrm{Al}_{0.25} \mathrm{Ga}_{0.75} \mathrm{As}$ blocking layers. The wider $\mathrm{E}_{\mathrm{g}}$ materials of the $\mathrm{p}-\mathrm{i}-\mathrm{n}$ diode were GaAs with doping densities equal to $1 \times 10^{17} \mathrm{~cm}^{-3}$ for $\mathrm{p}$ and $5 \times 10^{17} \mathrm{~cm}^{-3}$ for $\mathrm{n}$, respectively. The samples were finalized by a $500 \mathrm{~nm}$ thick highly $\mathrm{n}$ doped GaAs cap. The $1250 \mathrm{~nm}$ thick GaInNAs layers were grown without any intentional doping, usually resulting in $\mathrm{p}-$ type material with carrier concentrations of low $10^{16} \mathrm{~cm}^{-3}$ and a depletion layer width that extends more than $250 \mathrm{~nm}$ into the GaInNAs layer. Photo-excited electron-hole pairs, which are generated or diffuse into that region, are effectively separated and no additional electric field is needed.

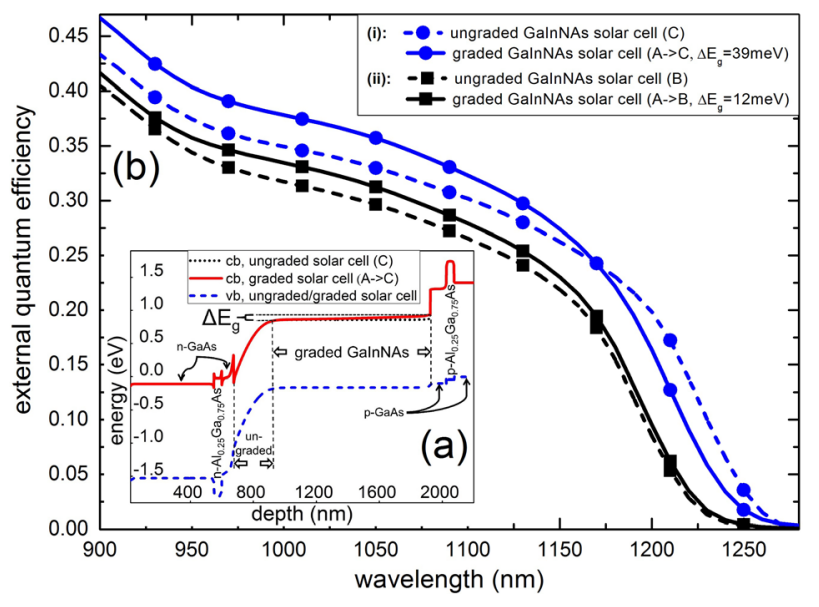

FIG. 2. (a) Band lineup of the pin-GaInNAs solar cells. The cb of the compositionally graded GaInNAs solar cell (red line) is raised $39 \mathrm{meV}$ relative to the $\mathrm{vb}$ in a linear way from the end of the depletion layer to the beginning of the p-GaAs base. The cb band from the reference solar cell with an ungraded GaInNAs layer remains flat. The valence band (vb, blue line) almost stays at the same level for both types of solar cells. (b) EQE measurements of the GaInNAs solar cells with a compositionally graded GaInNAs layer (continuous black and blue line) and for the ungraded solar cells with an ungraded GaInNAs layer (broken black and blue line). (i) Blue circles, $\Delta \mathrm{E}_{\mathrm{g}}=39 \mathrm{meV}$ : From $900 \mathrm{~nm}$ to $1175 \mathrm{~nm}$, an increased collection of photo generated carriers can be seen for the graded solar cell. Close to the band edge the $\mathrm{EQE}$ of the graded solar cell is decreasing faster than it is the case for the ungraded cell (cell C). (ii) Black rectangles, $\Delta \mathrm{E}_{\mathrm{g}}=12 \mathrm{meV}$ : The $\mathrm{EQE}$ is slightly increased over the complete spectrum. The loss of absorption near the band gap is quite small and cannot be seen.

Consequently, $250 \mathrm{~nm}$ of the GaInNAs layer has been grown with ungraded composition. The following $1000 \mathrm{~nm}$ of GaInNAs has been graded in the same manner as already explained for the samples $\mathrm{A} \rightarrow \mathrm{C}(\mathrm{A} \rightarrow \mathrm{B})$. The cb edge of the compositionally graded GaInNAs solar cell $\mathrm{A} \rightarrow \mathrm{C}$ (red straight line) is slowly increasing towards the p-GaAs base. The resulting internal electric field can be calculated to be $390 \mathrm{~V} / \mathrm{cm}$ for cell $\mathrm{A} \rightarrow \mathrm{C}$. According to values given in the literature ${ }^{4,15}$ for $1.0 \mathrm{eV}$ GaInNAs, the electron mobility lies in the range of (100-300) Vs/ $\mathrm{cm}^{2}$, whereas the lifetimes of the electron minority carriers is in the range of $(0.3-0.7) \mathrm{ns}$. Using these values, a charge carrier drift distance of more than $100 \mathrm{~nm}$ for the case $\mathrm{A} \rightarrow \mathrm{C}$ can be estimated.

From the epitaxial material, solar cells with $0.64 \mathrm{~cm}^{2}$ active area were fabricated. The front contacts are $30 \mu \mathrm{m}$ broad fingers covering the active material and the back contact is planar. The contact material is an annealed $\mathrm{Au} / \mathrm{Ge}$ alloy and the electrical isolation of the p-i-n junction was done by electron cyclotron resonance reactive ion etching of a mesa structure. Measurements of the external quantum efficiency (EQE) were performed by illuminating the solar cells with light of a xenon lamp that was spectrally filtered by a grating monochromator. The photon flux used to obtain the EQE from the measurement current was calculated from the power spectrum of the filtered light recorded with a power meter (Coherent FieldMaster-GS with Ge-detector). The power meter is factory calibrated and the signal-to-noise ratio during the measurements was in the range of $10^{2}-10^{3}$. There was no bias voltage applied and all measurements were performed at $25^{\circ} \mathrm{C}$. Light current-voltage photovoltaic measurements were performed using the full spectrum of a xenon lamp (the power density of the lamp is about one third 
of AM0) shining on the solar cell. The open circuit voltage $\left(\mathrm{V}_{\mathrm{OC}}\right)$ of the solar cell with the grading $\mathrm{A} \rightarrow \mathrm{C}(\mathrm{A} \rightarrow \mathrm{B})$ was measured to be $0.40 \mathrm{~V}(0.39 \mathrm{~V})$ and the $\mathrm{V}_{\mathrm{OC}}$ of the corresponding reference cell $\mathrm{C}(\mathrm{B})$ was $0.42 \mathrm{~V}(0.42 \mathrm{~V})$. The slightly decreased values of the graded GaInNAs cells can be explained with the more complex growth procedure promoting the formation of material defects (e.g., dislocations due to local strain). The short circuit current density $\mathrm{J}_{\mathrm{SC}}$ of the graded cell $\mathrm{A} \rightarrow \mathrm{C}(\mathrm{A} \rightarrow \mathrm{B})$ was measured to be $3.71 \mathrm{~mA} / \mathrm{cm}^{2}\left(3.21 \mathrm{~mA} / \mathrm{cm}^{2}\right)$ and for the ungraded cell $\mathrm{C}(B)$ to $3.51 \mathrm{~mA} / \mathrm{cm}^{2}\left(3.05 \mathrm{~mA} / \mathrm{cm}^{2}\right)$. However, one has to note the different absorption edges of the solar cells. The fill factors (FFs) of the solar cell with the compositional grading A $\rightarrow \mathrm{C}(\mathrm{A} \rightarrow \mathrm{B})$ was calculated to be $63 \%(60 \%)$ and the FFs of the cell C (B) was 65\% (63\%). Fig. 2(b) shows EQE measurements of the solar cells. Considering (i) (blue circles, representing the cell $\mathrm{A} \rightarrow \mathrm{C}$ with $\Delta \mathrm{E}_{\mathrm{g}}=39 \mathrm{meV}$ and its reference cell $\mathrm{C}$ ) it can be seen that the $\mathrm{EQE}$ increases going to shorter wavelengths because of the increasing absorption coefficient until the GaAs cap starts to absorb below $900 \mathrm{~nm}$. Near the $\mathrm{E}_{\mathrm{g}}$ of the GaInNAs material, the reference cell $\mathrm{C}$ (blue broken line) starts to absorb around $1250 \mathrm{~nm}$, whereas the onset of the absorption measured for the compositionally graded cell is located around $1240 \mathrm{~nm}$. This discrepancy is due to the fact that the $\mathrm{E}_{\mathrm{g}}$ of the graded cell was gradually increased and the absorption coefficient rapidly decreases for photon energies close to the $E_{g}$. However, for the remaining spectrum beginning at $1175 \mathrm{~nm}$ down to $900 \mathrm{~nm}$, the graded solar cell $\mathrm{A} \rightarrow \mathrm{C}$ (blue continuous line) shows an increased $\mathrm{EQE}(36.6 \%)$-relative to the reference cell $(\mathrm{EQE}=34.0 \%)$ - of about $8 \%$ in average. This shows the improved extraction of the photo generated charge carriers in the GaInNAs layer due to the additional electric field in the solar cell $\mathrm{A} \rightarrow$ $\mathrm{C}$, which is absent in the reference solar cell $\mathrm{C}$. Considering (ii) (black rectangles, representing the cell $\mathrm{A} \rightarrow \mathrm{B}$ with a $\Delta \mathrm{E}_{\mathrm{g}}=12 \mathrm{meV}$ and its reference cell $\mathrm{B}$ ) the graded GaInNAs solar cell (black continuous line) shows an increased average EQE of $32.1 \%$ beginning from the absorption edge located around $1230 \mathrm{~nm}$ down to $900 \mathrm{~nm}$ with a relative increase of $5 \%$ in average compared to the ungraded solar cell B (black broken line).

Before we further interpret these results, we want to note that variations in the electrically active carrier density within the GaInNAs layers producing an additional potential gradient cannot be excluded due to changing the As/III ratio during the growth of the graded GaInNAs layers. We have already shown in our previous work that increasing the As/ III ratio can increase the effective p-type doping. ${ }^{16}$ However, the potential gradient due to variation in the doping profile should point in the opposite direction as the gradient due to variation in the band gap. As an upper limit, the gradient across the GaInNAs caused by doping can be estimated to be $16 \mathrm{meV}$ (based on doubling the p-type doping from $2 \times 10^{16} \mathrm{~cm}^{-3}$ to $4 \times 10^{16} \mathrm{~cm}^{-3}$ correlating with decreasing the band gap of cell $\mathrm{A} \rightarrow \mathrm{C}$ ). It seems obvious that the graded cells show an improved collection of photo generated carriers below $1150 \mathrm{~nm}$. However, only for the cell $\mathrm{A} \rightarrow \mathrm{B}$, the small loss of absorption close to its absorption edge can be overcompensated with an improved extraction of charge carriers. It might be possible that the material grading $\mathrm{A} \rightarrow$
B is acting as a potential barrier for electrons diffusing in the wrong direction, and has very little influence on the absorption process in this special case. Taking these findings into account, it could be advantageous to start the material grading on the higher side with the $\mathrm{E}_{\mathrm{g}}$ the solar cell shall start to absorb and decrease it to somewhat lower values to avoid losses in absorption efficiency for stronger graded material. However, this most likely comes along with a reduction of the $\mathrm{V}_{\mathrm{OC}}$.

In conclusion, we have fabricated compositionally graded GaInNAs material with a $\Delta \mathrm{E}_{\mathrm{g}}$ of up to $39 \mathrm{meV}$ from one side of the layer to the other. PL measurements under excitation from different directions have clearly shown the influence of the potential gradient in the GaInNAs layer. We integrated the graded GaInNAs in solar cell structures. The graded solar cells showed an increased EQE-relative to an ungraded cell - of up to $8 \%$ leading to an enhanced $\mathrm{J}_{\mathrm{SC}}$. However, we observed a small shift of the absorption edge after $\Delta \mathrm{E}_{\mathrm{g}}$ was increased from $12 \mathrm{meV}$ up to $39 \mathrm{meV}$. One can conclude that the loss of absorption close to $E_{g}$ will become dominant if the gradient will be increased even further leading to a decreased $\mathrm{J}_{\mathrm{SC}}$ of a graded solar cell. The $\mathrm{V}_{\mathrm{OC}}$ of our fabricated graded solar cells is slightly decreased compared to the ungraded cells. We believe that it should, in principle, be possible to solve the trade-off between the increased $\mathrm{J}_{\mathrm{SC}}$ and the decreased $\mathrm{V}_{\mathrm{OC}}$ by further optimizing the growth process of the graded material to increase its crystal quality. Our initial results show that a material grading can in principle help to improve the charge carrier extraction in a GaInNAs solar cell. However, an optimized layout of a GaInNAs solar cell has to be carefully chosen and the material gradient might only be one feature among others (e.g., doping gradient, broad depletion width) promoting the current generation.

This work was financially supported by the "Deutsches Zentrum für Luft- und Raumfahrt e.V." (DLR) under the project "Solarzellenkonzepte für Raumfahrtgeneratoren der nächsten Generation" (SoNG, Contract No. 50RN1301). The authors would like to thank Tobias Roesener and Florian Wolf from the AZUR SPACE SOLAR POWER GmbH for contributing the PL measurements and Selina Handel for sample preparation. S.H. gratefully acknowledges the support by the Royal Society and the Wolfson Foundation.

\footnotetext{
${ }^{1}$ See www.ise.fraunhofer.de for PI Nr. 26/14, 2014.

${ }^{2}$ V. Sabnis, H. Yuen, and M. Wiemer, AIP Conf. Proc. 1477, 14 (2012).

${ }^{3}$ S. R. Kurtz, A. A. Allerman, E. D. Jones, J. M. Gee, J. J. Banas, and B. E. Hammons, Appl. Phys. Lett. 74(5), 729 (1999).

${ }^{4}$ D. B. Jackrel, S. R. Bank, H. B. Yuen, M. A. Wistey, J. S. Harris, A. J. Ptak, S. W. Johnston, D. J. Friedman, and S. R. Kurtz, J. Appl. Phys. 101, 114916 (2007).

${ }^{5}$ A. Aho, V. Polojärvi, V. M. Korpijärvi, J. Salmi, A. Tukiainen, P. Laukkanen, and M. Guina, Sol. Energy Mater. Solar Cells 124, 150-158 (2014)

${ }^{6}$ R. J. Kaplar, S. A. Ringel, S. R. Kurtz, J. F. Klem, and A. A. Allerman, Appl. Phys. Lett. 80(25), 4777 (2002).

${ }^{7}$ S. R. Kurtz, A. Allerman, C. H. Seager, R. M. Sieg, and E. D. Jones, Appl. Phys. Lett. 77(3), 400 (2000).

${ }^{8}$ N. Miyashita, Y. Shimizu, and Y. Okada, J. Appl. Phys. 102, 044904 (2007).

${ }^{9}$ J. Toivonen, T. Hakkarainen, M. Sopanen, H. Lipsanen, J. Oila, and K.
} Saarinen, Appl. Phys. Lett. 82, 40 (2003). 
${ }^{10}$ W. Li, M. Pessa, T. Ahlgren, and J. Decker, Appl. Phys. Lett. 79, 1094 (2001). ${ }^{11}$ A. Janotti, S.-H. Wei, S. B. Zhang, C. G. Van de Walle, and S. R. Kurtz, Phys. Rev. B 67, 161201 (2003).

${ }^{12}$ D. Wagner and J. Shealy, Appl. Phys. Lett. 45, 162 (1984).

${ }^{13}$ T. Dullweber, G. Hanna, U. Rau, and H. Schock, Sol. Energy Mater. Solar Cells 67, 145-150 (2001).
${ }^{14}$ W. Shan, W. Walukiewicz, J. W. Ager, E. E. Haller, J. F. Geisz, D. J. Friedman, J. M. Olson, and S. R. Kurtz, Phys. Rev. Lett. 82(6), 1221 (1999).

${ }^{15}$ J. Geisz, D. J. Friedman, J. Olson, S. R. Kurtz, and B. Keyes, J. Cryst. Growth 195, 401 (1998).

${ }^{16}$ F. Langer, S. Perl, S. Höfling, and M. Kamp, Appl. Phys. Lett. 106, $063905(2015)$. 